Georges and colleagues ${ }^{7}$ suggested that all visible bronchogenic cysts should be completely resected because the majority of them will eventually become symptomatic or complicated. As shown in our case, some bronchogenic cysts have the potential of malignant transformation.

In conclusion, we believe that complete resection of any bronchogenic cyst is justified because of the minimal risk of malignant transformation and the much greater risk of cyst-related complications (eg, pneumothorax in our case).

\section{References}

1. Meyer H. Úber angeborene blasige Missbildung der Lungen, nebst einigen Bemerkungen über Cyanose aus Lungenleiden. Arch Patol Anat. 1859;16:78-95.
2. Moersch HJ, Clagget OT. Pulmonary cysts. J Thorac Surg. 1947;16: 179-94.

3. De Perrot M, Pache J-C, Spiliopoulous A. Carcinoma arising in congenital lung cysts. Thorac Cardiovasc Surg. 2001;49:184-5.

4. Cuypers P, De Leyn P, Capelle L, Verougstraete L, Demedts M, Deneffe G. Bronchogenic cysts: a review of 20 cases. Eur J Cardiothorac Surg. 1996;10:393-6.

5. Endo C, Imai T, Nakagawa H, Ebina A, Kaimori M. Bronchioalveolar carcinoma arising in a bronchogenic cyst. Ann Thorac Surg. 2000;69: 933-5.

6. Suen H-C, Mathisen DJ, Grillo HC, LeBlanc J, McLoud T, Moncure AC, et al. Surgical management and radiological characteristics of bronchogenic cysts. Ann Thorac Surg. 1993;55:476-81.

7. St Georges R, Deslauriers J, Duranceau A, Vaillancourt R, Deschamps C, Beauchamp G, et al. Clinical spectrum of bronchogenic cysts of the mediastinum and lung in the adult. Ann Thorac Surg. 1991;52:6-13.

\title{
A giant anterior mediastinal teratoma presenting as orthopnea and dysphagia in an adult
}

\author{
Vishwanath Golash, MS, FRCS, Sultanate of Oman
}

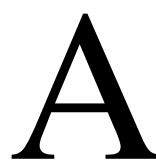

very large, mature, anterior teratoma in an adult woman presenting as orthopnea and dysphagia with bulging of the chest and neck is described. ${ }^{1,2}$ On excision, the mass was $27 \times 20 \times 11 \mathrm{~cm}$ in size and $14 \mathrm{~kg}$ in weight (inclusive of $8 \mathrm{~L}$ of cheesy aspirate during surgical intervention). I believe this is the largest and heaviest mediastinal teratoma ever reported in the literature.

\section{Clinical Summary}

A 20-year-old woman was referred from a remote area of a neighboring country with the diagnosis of tuberculous empyema of the left thorax and dextrocardia. ${ }^{3}$ She had received empiric antituberculous drugs for the preceidng few months. She provided a history of progressive difficulty in breathing, chest pain, and fullness on the left side of the chest for the past 2 years. She also had dysphagia for solids, weight loss, and fever for the past year.

On examination, she was orthopneic, emaciated, and in tachycardia. The trachea was shifted to the right. The left side of the

From the Department of Surgery, Sultan Qaboos Hospital, Sultanate of Oman.

Received for publication Jan 7, 2005; accepted for publication Feb 8, 2005

Address for reprints: Vishwanath Golash, MS, FRCS, Department of Surgery, Sultan Qaboos Hospital, PO Box 98, Salalah, Pin Code 211, Sultanate of Oman (E-mail: golash@omantel.net.om haritagolash@hotmail.com)

J Thorac Cardiovasc Surg 2005;130:612-3

$0022-5223 / \$ 30.00$

Copyright $\odot 2005$ by The American Association for Thoracic Surgery

doi:10.1016/j.jtcvs.2005.02.012 chest and the left supraclavicular area were visibly prominent and bulging. No air entry or apical beat was heard on the left side of the chest. The apical impulse was in the midaxillary line on the right side of the chest.

The results of routine

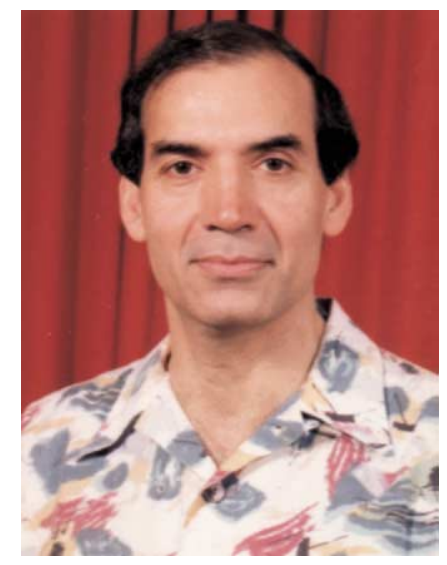

Dr Golash laboratory investigations were within normal limits. A plain chest x-ray film showed extreme displacement of the trachea, main bronchi, and heart to the right side caused by a huge mass or collection in the left hemithorax, which was seen as an opacity extending from the left supraclavicular area and pushing down the left diaphragm. Pleural aspirate was thick, purulent, and not free flowing. The cytology of the aspirated fluid showed no atypical cells, and the culture of the aspirate was sterile.

A barium swallow showed extreme displacement of the esophagus to the right and posteriorly caused by a mediastinum mass.

The fiberoptic bronchoscope revealed external compression and narrowing of all the divisions of the left main bronchus. The biopsy showed chronic inflammation, and sputum aspirate was sterile.

Ultrasonographic, computed tomographic, and magnetic resonance imaging scans of the chest showed the heart, great vessels, trachea, main bronchi, and right lung all displaced to the right side, with total collapse of the left lung caused by a large, well-defined, partially calcified mass of $25 \times 20 \times 9 \mathrm{~cm}$ in size with septum. It occupied the whole of the left side of the chest and extended from the left supraclavicular area to the left diaphragm to the right side 


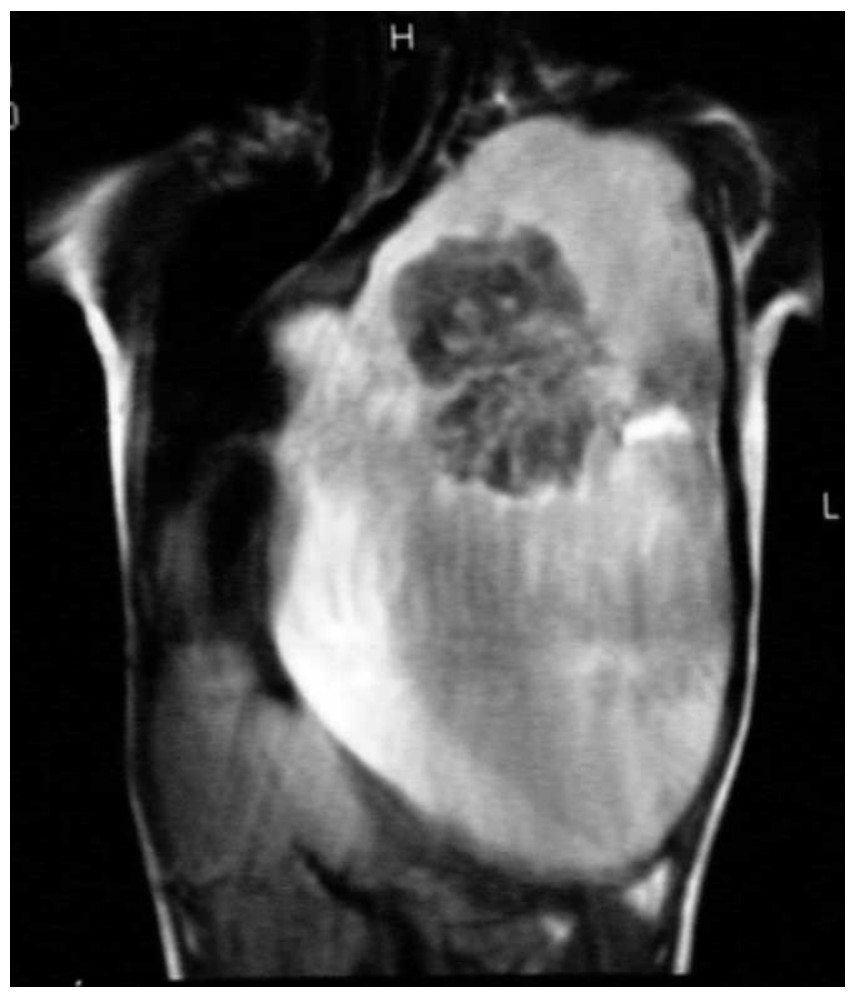

Figure 1. Magnetic resonance image of the chest.

of the chest with fat-fluid levels. The bulging and fullness seen in the left supraclavicular area was in continuity of the same mass. These findings were suggestive of a mediastinal teratoma (Figure 1). ${ }^{4}$

The cystic part of the mass was decompressed by aspiration of $8 \mathrm{~L}$ of thick, fatty, putty-like material mixed with hairs to facilitate excision during surgical intervention. ${ }^{2}$ The mass was completely excised intact with the excision of the surrounding adherent pleura (Figure 2).

\section{Results}

Postoperative recovery was uneventful. The histopathology showed elements of all 3 germinal layers. No immature elements were seen in the sections examined. She was followed up for 2 years and remained symptom free.

\section{Discussion}

Among all the germ cell tumors of the mediastinum, the cystic teratoma is the most common. The anterior mediastinum is the

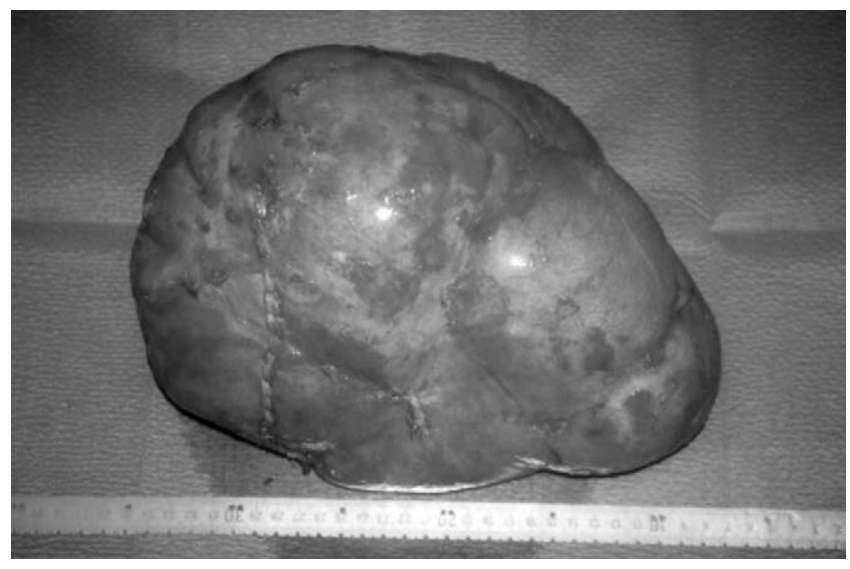

Figure 2. Excised specimen.

most common site. They are slow-growing benign tumors that usually become symptomatic as a result of mechanical pressure on mediastinal structure or through rupture and secondary infection. They contain elements of the 2 to 3 germinal layers. They account for $10 \%$ to $20 \%$ of the mediastinal lesions. They can be divided into mature solid, cystic, immature, malignant, and mixed. Immature teratomas account for $1 \%$ of mediastinal teratomas and mostly occur in men.

\section{Conclusion}

The mature mediastinal teratoma becomes symptomatic only when invading or during compression on the neighboring mediastinal structures. Surgical intervention is the only curative treatment and is advisable even when the patient is asymptomatic because of the potential of complications.

\section{References}

1. Freud E, Ben-Ari J, Schonfeld T, Blumenfeld A, Steinberg R, Dlugy E, et al. Mediastinal Tumors in children: a single institution experience. Clin Pediatr (Phila). 2002;41:219-23.

2. Kuroiwa M, Suzuki N, Takahashi A, Ikeda H, Hatakeyama SI, Matsuyama S, et al. Life threatening mediastinum teratoma in a neonate. Pediatr Surg Int. 2001;17:235-8.

3. Ooshima M, Takahasi T, Matsumoto H, Sasaki N, Sato K, Takedo A, et al. Matured mediastinal teratoma with a giant cyst resembling pleural effusion on X-ray films. Nihon Kokyuki Gakkai Zasshi. 1999;37:509-13.

4. Erasmus JJ, McAdams HP, Donnelly LF, Spritzer CE. MR imaging of mediastinal masses. Magn Reson Imaging Clin N Am. 2000;8:59-89. 